\title{
Timor Mountain Gum Improvement Program in Eastern Thailand
}

\author{
Mandy Maid (Corresponding author) \\ School of International Tropical Forestry \\ Universiti Malaysia Sabah \\ Locked Bag No 2073, 88999 Kota Kinabalu, Sabah, Malaysia \\ Tel: 60-88-320-000-8602 E-mail: Mandy21@ums.edu.my \\ Suree Bhumibhamon \\ Mae Fah Luang University Botanical Garden \\ 333 Moo1, Thasud Muang, Chiang Rai 57100, Thailand \\ Tel: 66-53-916-0278 E-mail: suree@mfu.ac.th
}

The research was supported by Thai Plywood Company-Lad Krating Plantation for the establishment and maintenance of the experiments and technical support.

\begin{abstract}
Timor Mountain Gum (Eucalyptus urophylla S.T. Blake) is an important eucalypts species for pulp and chip wood production in Thailand because of its rapid growth and suitability for hybridization. The 16 year-old provenance trials compared 19 natural seed sources in four blocks replication from the islands of Timor, Flores, Alor, Lomblen, Wetar, and Pantar. Seeds were collected from selected plus trees of the provenance trials to establish $F_{1}$ progeny test which comprise of 80 half-sib families in 12 blocks replication. In both experiments there were significant differences of growth performances and morphological characteristics among seed sources. A lowland provenance from Mt. Lewotobi, Flores indicated best growth in both the provenance trials and progeny test. The experiments implied that individuals from the island of Timor and Flores were the best performing. Therefore, these should be considered in the next selection process for breeding strategy to optimize plantation productivity.
\end{abstract}

Keywords: Eucalyptus urophylla, Provenance, Progeny, Variation

\section{Introduction}

Eucalypts contribute substantially to Thailand's 3.09 million ha (FAO, 2007) of forest plantations for the production of wood fuel, sawn wood, poles, and pulp for paper and paperboard. The eucalypts are not only important industrial species, but also made significant economic contribution to the income of small-holders. The most common species planted is Eucalyptus camaldulensis, E. urophylla and E. deglupta. The current status of eucalypts as commercial forest plantation species is the result of a series of field trials and testing that was conducted intensely throughout the country since the 1940s. Significant achievements in eucalypts tree improvement research in Thailand were attributed to a series of cooperation between the Thai Royal Forest Department and international agencies. The most notable effort was the preliminary planting of 15 Eucalyptus species with pulpwood potential in four experimental stations. Then, the Thai-Danish Pine and Fast-growing Tree Improvement Project (1972) and an ACIAR-CSIRO Forestry and Forest Products (1985-1986) supported project led to the establishment of ex-situ gene conservation stands of selected species prominently E. brassinana, E. camaldulensis, and E. urophylla in Surin. The later trial confirmed the suitability of E. camaldulensis and E. urophylla for planting in most parts of Thailand (Pousajja, 1993; Luangviriyasaeng, 2003).

Recent observations indicated that some eucalypts species and provenances may be susceptible to pest and diseases such as shoot blight and progressive canker, which causes chronic defoliation, reduction in growth rate and the loss of merchantable volume. Subsequently, tree improvement programs of eucalypts in Thailand will have to seriously consider the selection and screening programs for resistance towards pest and diseases (Pongpanich, 1998). Eucalypts hybrid breeding is actively being pursued for this purpose. This paper will describe the improvement and breeding activities for E. urophylla as one of the most promising species. In addition for the establishment of short rotation forest, the species is potentially suitable for windbreaks and soil salinity control whereby these problems are prevalent in some parts of Thailand. 


\section{Materials and Methods}

\subsection{Experimental site}

The experiments were established at Lad Krating Plantation of Sanam Chaikhet District in Chachoengsao province. It is located on a relatively flat area (altitude $80 \mathrm{~m}$ ) about $90 \mathrm{~km}$ east of Bangkok, Thailand at latitude $13^{\circ} 42^{\prime} \mathrm{N}$ and longitude $101^{\circ} 06^{\prime} \mathrm{E}$. Mean annual temperature is $28^{\circ} \mathrm{C}$ and mean annual rainfall is $1,220 \mathrm{~mm}$ with a dry period occurring between Novembers to February. Soil is sandy clay loam of the Clayey-skeleton, Kalinite, Aeric Kanhapustult Series.

\subsection{Experimental design}

The provenance trials which were established in 1988 compared 23 natural seed sources from the islands of Timor, Flores, Alor, Lomblen, Wetar, and Pantar (Table 1). The provenance trials were laid out in Randomised Complete Block Design (RCBD) of four replicates which consists of five rows of four columns each. Each plot was planted with five rows of five trees at $4 \times 4 \mathrm{~m}$ spacing.

The seeds from 188 selected plus trees from the E. urophylla provenance trials were planted and tested for initial survival and growth rates. Subsequently, the best performing 80 half-sib families were selected from the 188 plus trees to establish the progeny tests (Table 1) in May 2002. The progeny test was laid out in RCBD with 12 replicates each consisting of 10 rows by eight columns. Each plot was planted with four rows of four trees with a spacing of $1 \mathrm{x}$ $2 \mathrm{~m}$. Both experiments were protected by rows of shelterbelts and weeding was carried out at least once a year. The progeny stand was thinned by phenotypic selection in October 2004 and June 2005 by $50 \%$ selection at each time. The final thinning will convert the progeny tests to a seedling seed orchard.

\subsection{Assessment}

The provenance trials were assessed periodically at the ages of 6, 8, 10 and 16 years old. The first assessment of the progeny test was carried out at 3 years old. For both experiments the height $(\mathrm{Ht})$, diameter at $1.3 \mathrm{~m}$ above ground $(\mathrm{dbh})$, diameter at ground level (dgl), crown diameter $(\mathrm{Cr})$ and stem straightness were measured. Bark characteristics were also assessed for the provenance trials. Narrow sense family heritability $\left(\mathrm{h}_{\mathrm{f}}^{2}\right)$ was estimated from the half-sib progeny test using the formula by Zobel and Talbert (1984):

$$
\begin{gathered}
h_{f}^{2}=-\ldots{ }^{2} \\
h^{2}{ }_{f}=1-1 / F
\end{gathered}
$$

Where:

$$
\begin{array}{ll}
\sigma_{\mathrm{f}}^{2} & =\text { Variance among families } \\
\sigma_{\mathrm{e}}^{2} & =\text { Error variance } \\
\mathrm{n} & =\text { Number of individuals per family } \\
\mathrm{F} & =\text { F-ratio of families from ANOVA }
\end{array}
$$

The phenotype and genotype values of progenies were calculated with the following formula by Falconer (1960):

$$
\mathrm{G}=\mathrm{h}^{2} \times \mathrm{P}
$$

$$
\begin{gathered}
\text { Mean value of families }- \text { Total mean average } \\
\text { P }=\text { Total mean average }
\end{gathered}
$$

Where:

$$
\begin{aligned}
\mathrm{G} & =\text { Genotypic value }(\%) \\
\mathrm{h}^{2} & =\text { Heritability } \\
\mathrm{P} & =\text { Phenotypic value }(\%)
\end{aligned}
$$




\subsection{Data analysis}

Variation of tree growth performances were analysed using the Analysis of Variance (ANOVA) using SPSS statistical software (SPSS Inc., 2002). The Duncan's New Multiple Range Test (DNMRT) was used to compare means of the various characteristics among the provenances. Narrow sense family heritability was calculated for the progeny stand.

\section{Results And Discussion}

\subsection{Survival and growth}

The mean survival percentages of E. urophylla in the provenance trials (Table 2) was high ( $>75 \%$ ) during the first 10 years, but decreased sharply after that (54.3\% at 16 years). Survival in the progeny trials (Table 3$)$ at age three years old was very high at $97.3 \%$. This indicates that at this site, the species is very suitable for the establishment of short rotation plantation. However, two provenances (Mt. Mandiri, Flores; Lelogama, Timor) had more than $70 \%$ survival at 16 years and may be considered for sawn timber production. The provenances that had the lowest survival (Mt. Wulogai, Flores; Mt. Mutis, Timor; Mt. Lakaan, Timor) originate from areas above $1500 \mathrm{~m}$ altitude which performs poorly in the lowland tropics (Faridah Hanum and Maesen, 1997). Furthermore, the altitudinal level was positively correlated with provenance $(0.324, p \leq 0.01)$ and negatively correlated with survival $(-0.457, p \leq 0.01)$. Significant differences $(p \leq 0.01)$ between the provenances (Table 2) and families (Table 3) occurred at all ages.

The species attain its greatest height increment during the first six years $(18 \mathrm{~m})$ and the subsequent 10 years height increment was only $7 \mathrm{~m}$ in the provenance trials. Its progenies attain even greater mean height increment at $12.1 \mathrm{~m}$ at three years old. Provenance (Mt. Lewerok, Flores; Mt. Lewotobi, Flores; Kalabahi, Alor) which are of lowland origin $(<1200 \mathrm{msl})$ had the best height implying a genetically inherent characteristics. There were significant differences $(\mathrm{p} \leq 0.01)$ between the provenances and families at all ages.

Diameter at breast height (Dbh) and diameter at ground level (Dgl) have similar increment trend as height for both experiments. The greatest mean Dbh increment for the provenance trials was during its initial six years of $16.3 \mathrm{~cm}$, and subsequent 10 years was followed with Dbh increment of $7.2 \mathrm{~cm}$. In the first three years of progeny testing establishment mean Dbh was $10.4 \mathrm{~cm}$. There were significant differences $(\mathrm{p} \leq 0.01)$ between provenances and families at all ages for both characteristics. Provenance from Mt. Lewotobi, Flores was the best in terms of Dbh and Dgl. Pearson's correlation analysis revealed positive correlations $(0.05<\mathrm{R}<0.92)$ amongst all growth characteristics of $E$. urophylla progenies and was statistically significant $(\mathrm{p} \leq 0.01)$.

Analyses of variance for crown diameter and stem form were also performed for the progeny tests (Table 3). Mean crown diameter was $1.9 \mathrm{~m}$. There were significant differences $(\mathrm{p} \leq 0.01)$ between families for crown diameter and stem form. Fig. 2 shows that the distribution of stem forms in the provenance trials have less than $20 \%$ of straight stem trees, but ANOVA showed insignificant differences between the provenances. In the progeny tests more than $80 \%$ were straight stem, which could be attributed to the selection process that favoured straight stem and high clear bole. However, it could be argued that during the initial fast growth phase the trees tend to develop straighter stem and due to the closer planting arrangement in the progeny tests compared to wider-spaced provenance trials which have led to growth competition.

In general, the results of the provenance trials indicated that some lowland provenances of narrow altitudinal range from the islands of Flores, Alor, Lomblen had good growth at the experimental site. Conversely, provenance from high altitudinal sources (Wetar Island) did not perform well here. Brazil (Scanavaca and Garcia, 2003) and China (Wei and Borralho, 1998) had been actively working on the improvement and breeding of E. urophylla from the island of Flores which provides most of their planting material for the plantation industry. The achievements in tree improvement program have been fruitful in Brazil since some lowland landraces were found to be superior to their more recently introduced wild relatives.

\subsection{Heritability estimates}

Heritability (Table 3) was moderately high for all growth traits (height 0.61 , Dbh 0.77 , Dgl 0.74, crown diameter 0.51, stem form 0.51 ) with the exception of survival (0.30). Survival may not be a heritable character but was highly influenced by environmental factors. On average, phenotypic and genotypic value comprised of more than $80 \%$ and less than $60 \%$ respectively for height, Dgl, crown diameter and stem forms for most growth characteristics. Thus, selection process based on phenotypic characteristic can be reliable. Most fast growing species show to a great extent moderate to high heritability for the most important growth traits in the first three years of active growth which should be taken advantage for early selection to increase volume growth. Slow-growing temperate species such as pines generally have lower heritability compared to fast-growing species. In Pinus caribaea var hondurensis heritability was 0.10-0.24 and in P. elliottii was 0.20, although hybrid pines fared better (0.44) (Powell and Nickles, 1996). Long-lived E. marginata also showed very low heritability of growth traits (0.06-0.13) (O'Brien et al., 2007). Heritability assessment should be carried out periodically because some study points to enhanced heritability with increased ages up to its rotation age. For example, heritability of growth traits of E. camaldulensis in Thailand ranged 0.63-0.74 at 6 
months to 0.83-0.90 after 1 year (Pipatwattanakul, 1996), and similarly in E. urophylla trials in Veracruz, Mexico heritability increased with age at the individual (0.25-0.52) and clone mean levels (0.81-0.93) (Sánchez et al., 2005; Borje-de la Rosa et al., 2005). As research progresses with specific breeding objectives, future studies will have to include the heritability of other traits such as wood properties and flowering characteristics as other research indicated that these traits are strongly inherited (Atipanumpai, 1989).

\section{Conclusion}

Provenance trials and progeny tests of E. urophylla in Eastern Thailand showed significant morphological and growth variations. Heritability estimates was moderately high for all growth traits. The wide genetic content of the species provides opportunity to optimize plantation productivity and enhanced wood properties. Improvement and breeding plan should concentrate on lowland provenance from the islands of Flores, Alor and Lomblen.

\section{References}

Atipanumpai, L. (1989). Acacia mangium: studies on the genetic variation in ecological and physiological characteristics of a fast-growing plantation tree species. Acta Forestalia Fennica 206, 92.

Borja-de la Rosa, A., Vargas-Hernandez, J.J., Lopez-Upton, J., and Ignacio-Sanchez, E.. (2005). Genetic parameters for growth and wood density in juvenile Eucalyptus urophylla S.T. Blake. Agrociencia (Montencillo), 39(4),469-479.

Falconer, D.S. (1960). Introduction to quantitative genetics. Oliver and Boyd, Edinburgh.

Faridah Hanum, I. and van der Maesen, L.J.G. (Eds.). (1997). Plant resources of South-East Asia No. 11: auxiliary plants. Prosea Foundation, Bogor, Indonesia. pp.140-144.

FAO. (2007). State of the world's forest 2007. FAO, Rome. pp.111.

Luangviriyasaeng, P. (2003). Eucalypt planting in Thailand, pp.28-31. In J.W. Turnbull, ed. Proceedings of an international conference, Eucalypts in Asia. ACIAR Proc. No. 111.

O’Brien, E.K., Mazanec R.A. and Krauss. S.L. (2007). Provenance variation of ecologically important traits of forest trees: implications for restoration. Journal of Applied Ecology, 44,583-593.

Pallett, R.N. and Sale, G. (2004). The Relative Contributions of Tree Improvement and Cultural Practice toward Productivity Gains in Eucalyptus Pulpwood Stands. Forest Ecology And Management, 193,33-43.

Pongpanich, K. (1998). Diseases of Eucalyptus in Thailand and options for reducing their impact, pp.47-52. In Hutacharern, C. and Nair, K.S.S. (Eds.) FORSPA Publication: 30/2002. Proceedings of the IUFRO/FAO workshop on forest management in tropical forest plantations. Chanthaburi, Thailand.

Pousajja, R. (1993). Eucalypt plantation in Thailand, pp.213-223. In Kashio, M. and White, K. (Eds.) FAO/RAPA Publication 1996/44, Regional Expert Consultation on Eucalyptus, Vol. II. Bangkok, Thailand.

Powell, M.B. and Nickles, D.G. (1996). Genetic parameter estimates and predicted breeding values for diameter, height, and stem straightness of Pinus elliottii, Pinus caribaea var hondurensis and their $\mathrm{F}_{1}$ hybrid, pp.169-172. In Dieters, M.J., Matheson, A.C., Nickles, D.G., Harwoods, C.E. and Walker, S.M. (Eds.). Proceedings QFRI-IUFRO Conference, Tree Improvement for Sustainable Tropical Forestry. Queensland Forestry Research Institute, Gympie.

Wei, X. and Borralho. N.M.G. (1998). Genetic control of growth traits of Eucalyptus urophylla S.T. Blake in South East China. Silvae Genetica 47,2-3

Sànchez, E.I., Hernandez, J.J.V., Upton, J.L. and de la Rosa, A.B. (2005). Genetic parameters for growth and wood density in juvenile Eucalyptus urophylla S.T. Blake. Agrociencia 39(4),469-479

Scanavaca Jr., L. and Garcia, J.N. (2003). Potential de melhoramento genético em Eucalyptus urophylla procedenteda Ilha Flores. Scientia Forestalis 64:23-32.

SPSS Inc. (2002). SPSS for Windows Version 11.5. SPSS Inc., U.S.

Zobel, B.J. and Talbert, J. (1984). Applied Forest Tree Improvement. John Wiley \& Sons Inc., New York. 
Table 1. Details of Eucalyptus urophylla seed sources for the provenance trials (1988) and progeny tests (2002) at Lad Krating Plantation, Thailand

\begin{tabular}{clcccc}
\hline $\begin{array}{c}\text { Provenance } \\
\text { No. }\end{array}$ & \multicolumn{1}{c}{ Provenance } & $\begin{array}{c}\text { Altitude } \\
(\mathbf{m})\end{array}$ & $\begin{array}{c}\text { Latitude } \\
(\mathbf{S})\end{array}$ & $\begin{array}{c}\text { Longitude } \\
(\mathbf{E})\end{array}$ & $\begin{array}{c}\text { No. of } \\
\text { families }\end{array}$ \\
\hline 1 & Mt. Egon, Flores & $400-890$ & $8^{\circ} 36^{\prime}$ & $122^{\circ} 28^{\prime}$ & 9 \\
2 & Mt. Wulogai, Flores & $1140-1240$ & $8^{\circ} 33^{\prime}$ & $121^{\circ} 48^{\prime}$ & 3 \\
3 & Mt. Wokoh, Flores & $850-900$ & $8^{\circ} 33^{\prime}$ & $122^{\circ} 36^{\prime}$ & 5 \\
4 & Mt. Lewerok, Flores & $500-550$ & $8^{\circ} 15^{\prime}$ & $122^{\circ} 40^{\prime}$ & 3 \\
5 & Mt. Mandiri, Flores & $500-650$ & $8^{\circ} 30^{\prime}$ & $122^{\circ} 54^{\prime}$ & 2 \\
6 & Mt. Lewotobi, Flores & $450-550$ & $8^{\circ} 22^{\prime}$ & $123^{\circ} 39^{\prime}$ & 8 \\
7 & Mt. Kerbau, Lomblen & $420-820$ & $8^{\circ} 22^{\prime}$ & $123^{\circ} 36^{\prime}$ & 3 \\
8 & Mt. Boleng, Flores & $915-1025$ & $8^{\circ} 21^{\prime}$ & $123^{\circ} 35^{\prime}$ & 1 \\
9 & Kalabahi, Alor & $450-850$ & $8^{\circ} 10^{\prime}$ & $124^{\circ} 41^{\prime}$ & 2 \\
10 & Ampui, Alor & $800-1200$ & $8^{\circ} 10^{\prime}$ & $124^{\circ} 41^{\prime}$ & 4 \\
11 & Mt. Sirung, Pantar & 760 & $8^{\circ} 26^{\prime}$ & $124^{\circ} 03^{\prime}$ & 6 \\
$12^{*}$ & Mt. Mutis, Timor & $800-2200$ & $8^{\circ} 34^{\prime}$ & $124^{\circ} 11^{\prime}$ & 2 \\
13 & Mt. Delaki, Pantar & $680-780$ & $8^{\circ} 26^{\prime}$ & $124^{\circ} 03^{\prime}$ & 2 \\
14 & Mt. Wasbilla, Pantar & $750-800$ & $8^{\circ} 34^{\prime}$ & $124^{\circ} 14^{\prime}$ & 9 \\
15 & Remexio, Timor & $800-930$ & $8^{\circ} 35^{\prime}$ & $125^{\circ} 41^{\prime}$ & 3 \\
$16^{* *}$ & Hatuloi, Wetar & 250 & $7^{\circ} 54^{\prime}$ & $125^{\circ} 58^{\prime}$ & 1 \\
18 & Lelogama, Timor & $1200-1300$ & $9^{\circ} 34^{\prime}$ & $124^{\circ} 20^{\prime}$ & 7 \\
19 & Ermera, Timor & $500-1400$ & $9^{\circ} 13^{\prime}$ & $125^{\circ} 40^{\prime}$ & 6 \\
22 & Ililaku, Wetar & $350-550$ & $7^{\circ} 54^{\prime}$ & $125^{\circ} 58^{\prime}$ & 1 \\
23 & Mt. Lakaan, Timor & $1350-1550$ & $9^{\circ} 34^{\prime}$ & $124^{\circ} 05^{\prime}$ & 2 \\
\hline
\end{tabular}

* $\quad$ Provenance died out

** Provenance excluded from analyses (no replication)

Table 2. Results from the analyses of variance for growth characteristics of Eucalyptus urophylla provenance trials periodic assessment at Lad Krating Plantation

\begin{tabular}{|c|c|c|c|c|c|c|c|c|c|}
\hline $\begin{array}{c}\text { ASSESSMENT } \\
\text { PERIOD }\end{array}$ & & \multicolumn{2}{|c|}{6 years } & \multicolumn{2}{|c|}{8 years } & \multicolumn{2}{|c|}{10 years } & \multicolumn{2}{|c|}{16 years } \\
\hline $\begin{array}{l}\text { SURVIVAL } \\
\text { Trial mean (\%) }\end{array}$ & & \multicolumn{2}{|c|}{85.1} & \multicolumn{2}{|c|}{79.7} & \multicolumn{2}{|c|}{75.3} & \multicolumn{2}{|c|}{54.3} \\
\hline Source of variance & d.f. & $\mathrm{ms}$ & $\mathrm{F}$ & $\mathrm{ms}$ & $\mathrm{F}$ & $\mathrm{ms}$ & $\mathrm{F}$ & $\mathrm{ms}$ & F \\
\hline Replication & 3 & 342.10 & $4.91 *$ & 371.56 & $5.22 * *$ & 576.89 & $8.09 * *$ & 544.77 & $3.93 *$ \\
\hline Provenance & 22 & 426.62 & $6.21 *$ & 497.92 & $7.00 * *$ & 915.78 & $2.84 * *$ & 1230.31 & $8.87 * *$ \\
\hline Residual & & 69.66 & & 71.12 & & 71.34 & & 138.70 & \\
\hline \multicolumn{10}{|l|}{ TOTAL HEIGHT } \\
\hline Source of variance & df & $\mathrm{ms}$ & $\mathrm{F}$ & $\mathrm{ms}$ & $\mathrm{F}$ & $\mathrm{ms}$ & $\mathrm{F}$ & $\mathrm{ms}$ & $\mathrm{F}$ \\
\hline Replication & 3 & 7.49 & $5.07 * *$ & 5.20 & $1.70^{\mathrm{ns}}$ & 6.60 & $3.22 *$ & 46.09 & $10.82 * *$ \\
\hline Provenance & 22 & 10.51 & $6.21 * *$ & 19.61 & $6.42 * *$ & 13.06 & $6.37 * *$ & 12.69 & $2.98 * *$ \\
\hline Residual & & 1.48 & & 3.05 & & 2.05 & & 4.60 & \\
\hline \multicolumn{10}{|l|}{ Dbh } \\
\hline Trial mean $(\mathrm{cm})$ & & \multicolumn{2}{|c|}{16.3} & \multicolumn{2}{|c|}{17.7} & \multicolumn{2}{|c|}{18.9} & \multicolumn{2}{|c|}{23.6} \\
\hline Source of variance & df & $\mathrm{ms}$ & F & $\mathrm{ms}$ & F & $\mathrm{ms}$ & F & $\mathrm{ms}$ & $\mathrm{F}$ \\
\hline Replication & 3 & 2.52 & $1.21^{\mathrm{ns}}$ & 2.02 & $2.21^{\mathrm{ns}}$ & 1.80 & $1.85^{\mathrm{ns}}$ & 110.87 & $7.29 * *$ \\
\hline Provenance & 22 & 5.51 & $2.64 * *$ & 5.50 & $6.01 * *$ & 5.21 & $5.35 * *$ & 24.55 & $1.61^{* *}$ \\
\hline Residual & & 2.08 & & 0.91 & & 0.97 & & 15.20 & \\
\hline \multicolumn{10}{|l|}{ Dgl } \\
\hline Trial mean $(\mathrm{cm})$ & & \multicolumn{2}{|c|}{19.6} & \multicolumn{2}{|c|}{21.2} & \multicolumn{2}{|c|}{22.6} & \multicolumn{2}{|c|}{29.8} \\
\hline Source of variance & df & $\mathrm{ms}$ & F & $\mathrm{ms}$ & $\mathrm{F}$ & $\mathrm{ms}$ & F & $\mathrm{ms}$ & F \\
\hline Replication & 3 & 4.62 & $4.22 * *$ & 3.65 & $2.87 *$ & 4.24 & $3.21 *$ & 26.72 & $9.73 * *$ \\
\hline Provenance & 22 & 5.72 & $5.32 * *$ & 7.52 & $5.92 * *$ & 8.00 & $6.05 * *$ & 10.70 & $3.90 * *$ \\
\hline Residual & & 1.09 & & 1.27 & & 1.32 & & 2.74 & \\
\hline
\end{tabular}


Table 3. Results from the analyses of variance for growth characteristics of 3-year old Eucalyptus urophylla progeny tests at Lad Krating Plantation

\begin{tabular}{|c|c|c|c|c|c|c|c|c|c|c|}
\hline \multirow[t]{2}{*}{$\begin{array}{l}\text { Source of } \\
\text { variation }\end{array}$} & \multirow[t]{2}{*}{ df } & \multicolumn{2}{|c|}{$\begin{array}{c}\text { Survival } \\
(\%)\end{array}$} & $\begin{array}{l}\text { Total Height } \\
\text { (m) }\end{array}$ & \multicolumn{2}{|c|}{$\begin{array}{l}\text { Dbh } \\
\text { (cm) }\end{array}$} & \multicolumn{2}{|c|}{$\begin{array}{l}\mathrm{Dgl} \\
(\mathrm{cm})\end{array}$} & $\begin{array}{l}\text { Crown diam. } \\
\text { (m) }\end{array}$ & Stem form \\
\hline & & $\mathrm{ms}$ & F & $\mathrm{ms} \quad \mathrm{F}$ & $\mathrm{ms}$ & $\mathrm{F}$ & $\mathrm{ms}$ & $\mathrm{F}$ & $\mathrm{ms} \quad \mathrm{F}$ & $\mathrm{ms}$ \\
\hline Replicate & 11 & 0.29 & $2.27^{\mathrm{ns}}$ & $115.453 .8^{* *}$ & 6.98 & $6.20 * *$ & 18.4 & $12.4^{* *}$ & $3.6125 .62^{* *}$ & $20.047 .45^{* *}$ \\
\hline Family & 79 & 0.84 & $1.43^{* *}$ & $7.8 \quad 2.6^{* *}$ & 4.10 & $4.42 * *$ & 5.23 & $3.84 * *$ & $0.342 .05^{* *}$ & $5.562 .07 * *$ \\
\hline Residual & 89 & 0.42 & & 3.0 & 0.93 & & 1.35 & & 0.17 & 2.68 \\
\hline Mean & & & 7.3 & 12.1 & & 0.4 & & 3.8 & 1.9 & - \\
\hline $\mathrm{h}_{\mathrm{f}}^{2}$ & & & .30 & 0.61 & & .77 & & .74 & 0.51 & 0.52 \\
\hline
\end{tabular}

Ns Non-significant

* $\quad$ Significant differences $(\mathrm{p}<0.05)$

** Highly significant differences $(\mathrm{p}<0.01)$

Dbh: Diameter at breast height; $\quad$ Dgl: Diameter at ground level;

$\mathrm{h}_{\mathrm{f}}{ }^{2}$ : Family heritability

(a)

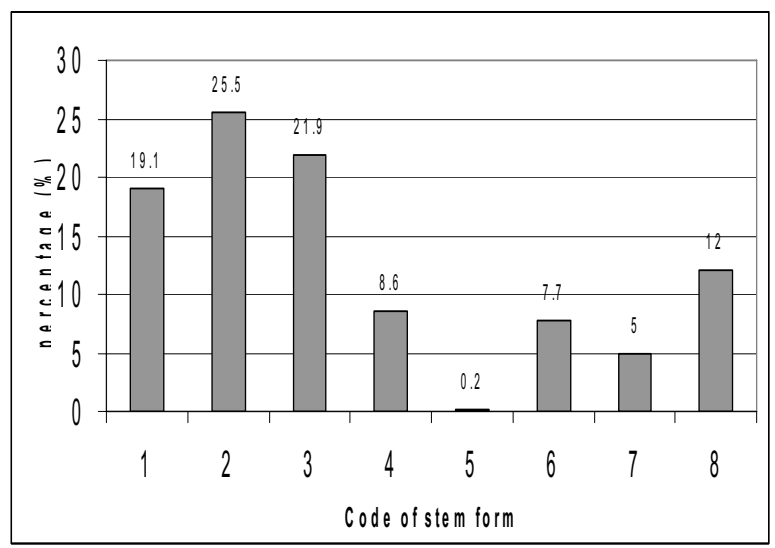

(b)

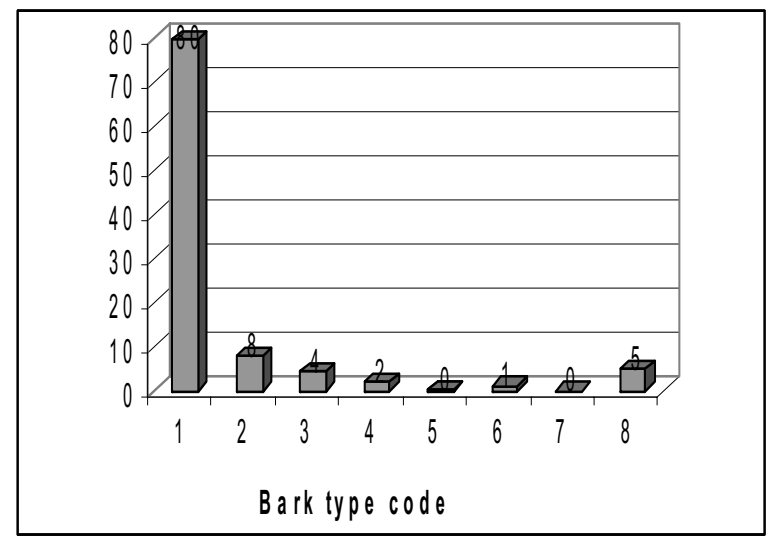

Stem forms: 1 Straight; 2 Curved; 3 Twisted, 4 Leaning, 5 Two Stem, 6 Two top, 7 Nested, 8 Short bole

Figure 1. Distribution of stem form in each experiment.

(a) Distribution of stem form in the provenance trials.

(b) Distribution of stem form in the progeny tests. 